\title{
Insecurity and Economic Growth in Nigeria: A Diagnostic Review
}

\author{
Bright Enakhe Onime, MSC; ACA; FMNES \\ Doctoral Research Student, University of Port Harcourt, Nigeria
}

Doi: 10.19044/esj.2018.v14n4p377 URL:http://dx.doi.org/10.19044/esj.2018.v14n4p377

\begin{abstract}
This paper examines the effect of insecurity on economic growth in Nigeria. Apart from its direct effect on the populace, it also affects the economy. Using elements of descriptive qualitative analysis and data from secondary sources, the paper analyzed its effect on some economic parameters. The analysis showed that insecurity affects economic growth by drying-out investments, increases unemployment and dwindles government revenue, amongst others. Despite these effects, government capital expenditure on internal security did not grow astronomically to match the hydra-headed problem. This paper therefore recommended an increase in capital expenditure on internal security and concludes with a discussion of some policies to be designed and targeted at addressing the economic effects of insecurity.
\end{abstract}

Keywords: Insecurity, Economic Growth, Conflict, Internal Security, Expenditure

\section{Introduction}

Insecurity in Nigeria has reached an alarming proportion showing its ugly head in various facets of our national life. Lives are lost on daily basis, population depleted, businesses in comatose, investments are nose-diving, multinationals closing shops and vacating the country, unemployment soaring and the populace in fears. Clearly, it poses a threat to governance and economic growth in troubled nations. According to Stewart (2004), the economic cost of insecurity are enormous. People who joined the fighting forces, who are killed or flee, can no longer work productively; schools, power stations, and roads that are destroyed reduced the productive capacity of the economy. Further, displacement of people reduces the production of exports, thereby reducing foreign exchange earnings, import potentials and consequently further constraining output, leading to a decline in employment and earnings. 
The menace remains a threat to governance and economic growth in Nigeria. Government by their inaction has proved to be unable to solely secure its citizens. Despite government's burgeoning recurrent expenditure on internal security both at the National and State levels, individuals in their various rights, work places and houses spend heavily to provide security for their personal lives and properties. Despite these efforts, the menace keep exacerbating. Thus in almost all parts of the country, there exist some levels of insecurity. We have seen instances of ethnic conflicts in some part of the North, kidnapping in almost all parts of the country, but prominent in SouthSouth and West, militancy and pipeline vandalisation activities in the Niger delta, terrorism and religious extremism by Boko Haram in North East, agitations for self-determination by IPOB (Indigenous People of Biafra) and MASSOB (Movement for the Actualization of the Sovereign State of Biafra) in South East, herdsmen disturbances in the North and Central, ritual killings in the South West and East and other political and economic disturbances. I posits that these disturbances and insecurities in its various forms affects economic growth.

Thus, it has been observed that in areas were insecurity are prone in Nigeria, economic activities and variables have been lagging behind. For instance, in the North East of Nigeria where Boko Haram has held sway, the area has been deserted, businesses including informal sector have been affected, unemployment have soared, Internally displaced persons (IDPs) and camps have suddenly emerged, State internally generated revenue have plummeted etc. Again, in the Niger Delta area of Nigeria where militant's attack on oil installations and pipeline vandalisation is persistent, a number of MNCs have closed shop or relocated their offices from the area, the country has been unable to meet its oil production quota, unemployment has skyrocketed, oil exports nosedived, foreign exchange dropped and the cost of doing business in the area have increased. So it is in the other parts of the country where insecurity strive.

In response, the federal government through its annual budgets, continue to vote huge allocation to the recurrent component of internal security, military personnel and apparatus have been asked to relocate their bases to the troubled areas to quell crises, and some States have signed into law the Anti-kidnapping Act while the National assembly passed the AntiTerrorism Act in 2011. Despite these measures, economic indices have not improved and the level of insecurity in the country is still high. A confirmation of this is the low ranking of Nigeria in the Global Peace Index (GPI, 2012) and the current recession the country has been thrown into.

The aim of this paper therefore is to review the various ways in which insecurity affects economic growth in Nigeria. To achieve this, the remaining section of this paper shall be organized as follows. Section two shall examine 
existing literature on subject, section three looks at the patterns and dimensions of insecurity in the country, section four considers the research method, section five provides an analysis of government expenditure on internal security, section six examined how insecurity affects economic growth, section seven tries to proffer a way out of the conundrum while section eight concludes the study.

\section{Literature review}

The devastating effects of insecurity on economic growth was recognized early enough in the literature. UNDP (1994), Beland (2005); Collier Paul (2006); Achumba and Ighomereho (2013); Omoyibo and Akpomera (2013); Stewart (2004); Aderoju (2007) amongst others. Most of this studies however examined the subject from a political-socio economic perspective, only a few purely economic study of the subject exist in the literature. UNDP (1994) defined human security with a view to understanding what insecurity entails. According to it, human security means, first, safety from such chronic threats as hunger, disease and repression. And second, it means protection from sudden and hurtful disruptions in the patterns of daily life - whether in homes, in jobs or in communities. The report identified seven elements that makes up human security: (i) Economic security; (ii) Food security; (iii) Health security; (iv) Environmental security; (v) Personal security; (vi) Community security; and (vii) Political security. Anything short of this definition and elements, amounts to insecurity.

According to Beland (2005) insecurity entails lack of protection from crime (being unsafe) and lack of freedom from psychological harm (unprotected from emotional stress resulting from paucity of assurance that an individual is accepted, has opportunity and choices to fulfill his or her own potentials including freedom from fear. As Achumba and Ighomereho (2013) puts it, those affected by insecurity are not only uncertain or unaware of what would happen but they are also not able to stop it or protect themselves when it happens. In respect of the factors responsible for insecurity and conflicts, Collier (2006) stressed that countries which have a substantial share of their income (GDP) coming from the export of primary commodities are radically more at risk of conflict. The most dangerous level of primary commodity dependence is $26 \%$ of GDP. According to him, conflicts and insecurity is concentrated in countries with little education, fast population growth and economic decline. This was also the views expressed by Aderoju (2007).

The effect of Insecurity on economic growth has been described to be negative. Stewart (2004) analyzed the effect of conflict and insecurity on development for twenty five countries between 1960 - 1995 and found that economic growth was almost always affected, agricultural sector was badly hit, exports were negative, production fell, there was a shift from international 
to domestic markets, imports went up dominated by military expenditure and essential consumption goods, usually leading to a shortage of foreign exchange for economic inputs., consumption per head fell, government revenue as a share of GDP mostly fell and foreign and private investments including government investment fell. This was further corroborated in SIPRI yearbook 2015, were they observed that threats to security can have socioeconomic roots, including contests over natural resources, spillover effects of environmental degradation, economic and social inequalities, economic and political migration, natural disasters, among others.

On the whole, this study is a departure from most of the existing literature as it examines the effect of insecurity on economy growth from a purely economic perspective.

\section{Patterns and Dimensions of Insecurity}

Nigeria is currently bedeviled by a plethora of civil unrests and insecurities including but not limited to the following;

- $\quad$ Armed robbery

- $\quad$ Kidnapping and Ritual killings

- $\quad$ High profile murder and political assassinations

- Herdsmen disturbances and clashes with farmers

- Violent agitations for resource control especially in Niger Delta of Nigeria

- Non-violent agitations for self-determination as observed in South East Nigeria

- $\quad$ Terrorist attacks epitomized by Boko Haram in North East Nigeria

- $\quad$ Ethnic and Religious tensions

- $\quad$ Communal and land disputes typified by Aguleri-Umuleri crises in Anambra State.

- Political/Post Election violence

- Etc.

In their own various ways, each dimensions of insecurity poses different risk to the polity. In recent times, incidences of kidnapping has gained prominence. The most celebrated of this cases of kidnapping was the 276 Chibok girls that were kidnapped from their school in Borno State and the millionaire kidnapper (Evans) case in Lagos. In respect of non-violent agitations for self-determination, the case of the Movement for the actualization of the Sovereign State of Biafra (MASSOB) and Indigenous People of Biafia (IPOB) stands out. Violent agitators for resource control especially in Niger Delta includes the activities of different militia groups including MEND, Ijaw Youth Council (IYC), Egbesu, Movement for the survival of Ogoni People (MOSOP) etc. In respect of militancy struggle in the 
Niger Delta, Aderoju (2007) attributes this to the 'resource curse', the tendency of natural resource dependence to cause slow growth, greater inequality and poverty for a larger majority of a country's population.

A number of reasons have been adduced for insecurity in Nigeria, including but not limited to the over dependence on oil, export of primary commodities, social inequality, state failure, human right violations, resource predation, corruption, feeling of marginalization and alienation etc. Policy to tackle insecurity therefore must first address these root causes of insecurity in other to be successful.

\section{Research Method}

Descriptive qualitative analysis was used to explain the data gathered for this study. This analysis according to Nnamdi Azika (2004), is used to verbally summarize the information generated in a research. It is theoretical with in-depth explanatory and illustrative description, producing results that give meaning, experience and views. As Tilahun Nigatu (2009) puts it, it is a range of processes and procedures whereby we move from the qualitative data that have been collected for a study into some form of explanation, understanding, or interpretation of the situations been investigated.

Using such descriptive qualitative analysis therefore and data from secondary sources, I analyzed the effect of insecurity (the dependent variable) on some economic parameters (explanatory variables) and established the direction of such effects. I sought to do this by utilizing tables, percentages, bar graphs and line charts. Bar charts as used in this study presents categorical data with rectangular bars and heights proportional to the values that they represent. Each bar's length is proportional to the bars represented values. The line charts on the other hand, displays information as a series of data points connected by straight line segments. They are used to display trends overtime. In sum, they provide a simple way to visualize a sequence of values.

Data for the study were obtained from secondary sources including the Central Bank of Nigeria, National Bureau of Statistics and OPEC annual reports. Reliance were placed on data from these agencies because of their method of data collection and the integrity of the data.

\section{Government Expenditure On Internal Security}

Various government has paid varied attention to this problem of insecurity in their own different ways. This is evident in the galloping nature of expenditure on security as shown in the table below;

Internal Security Expenditure (Nbillions)

\begin{tabular}{|c|c|c|c|c|c|}
\hline Expenditure item & 2011 & 2012 & 2013 & 2014 & 2015 \\
\hline Recurrent & 280.0 & 362.5 & 292.7 & 273.1 & 410.2 \\
\hline Capital & 65.7 & 58.10 & 12.1 & 48.3 & 36.0 \\
\hline Total & 345.7 & 420.6 & 304.8 & 321.4 & 446.2 \\
\hline
\end{tabular}


Source: CBN Annual Report, 2015

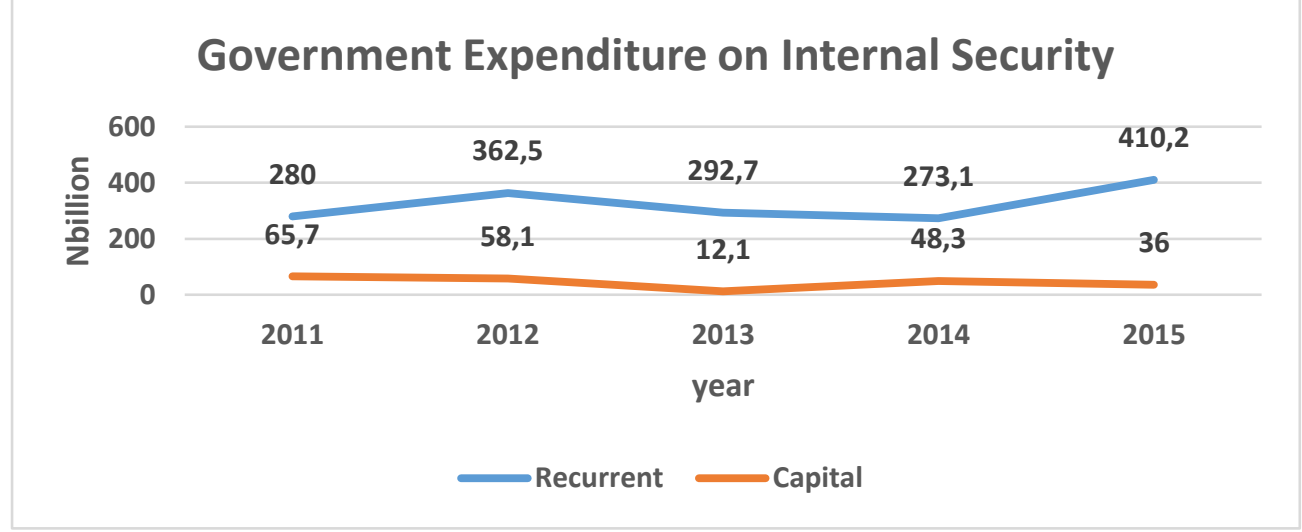

As shown, the recurrent component of internal security increased from N280billion in 2011 to N362.5 billion in 2012 representing 29\% increase over the figure in the previous year. This recurrent component skyrocketed by $13 \%$ to 410.2 in 2015 when compared to the figure in 2012. However, the capital component has not enjoyed the kind of increase in the recurrent. For instance, the capital component was N65.6billion in 2011, declining by $82 \%$ to N12.1billion in 2013.

\section{Government expenditure on Internal Security}

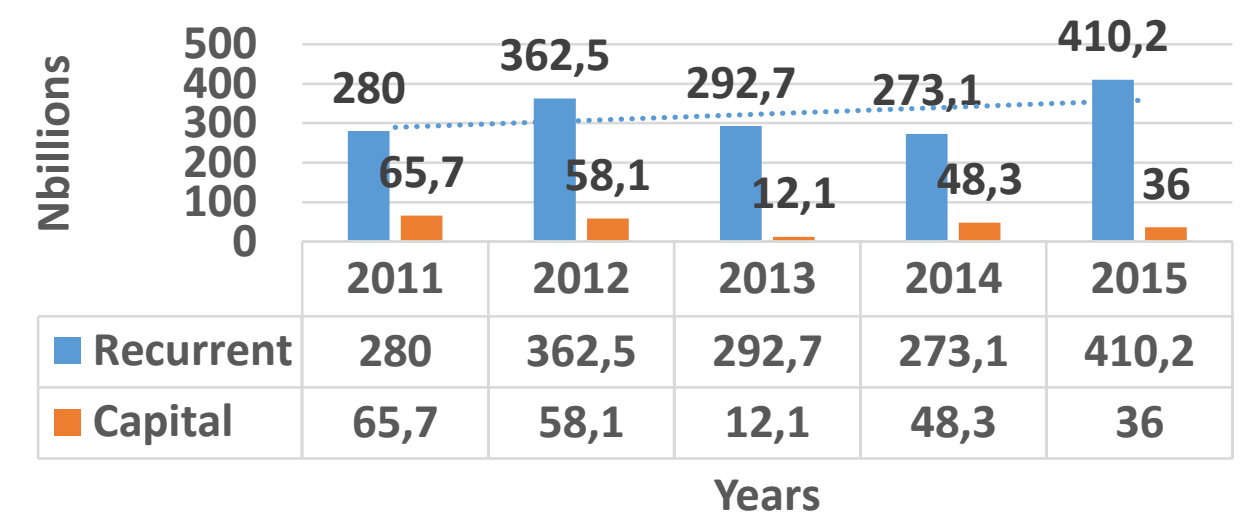

Clearly, while expenditure on the recurrent component remained on the increase, that of the capital component continued to decline over the years. This accounts for the poor state of security equipment including guns and surveillance devices available to our security operatives. Whereas the criminals and militants have very sophisticated weapons at their disposal, the nation's security and intelligence agencies barely have none. In some 
instances, capital budget earmarked for the procurement of security equipment ends up in private pockets. The case in point is the 'Dasukigate' corruption scandal currently been investigated. This is the case of billions of naira voted for the procurement of military equipment that was shared by the then Minister of Defense among prominent politicians under the President Jonathan's administration.

\section{Insecurity and Economic growth}

Insecurity rears its ugly heads in many facets of our national life. Clearly, the following are some of the areas this conundrum has affected Nigeria;

\section{Effect on Population}

The effect of insecurity on the population is obvious. Insecurity depletes the population as innocent, young and productive member of the population are wasted during periods of uprising. For instance, between 2009 and 2013, a whopping 1, 341 lives have been lost due to the activities of Boko haram in North Eastern part of Nigeria. A breakdown of that figure shows that the highest casualty was recorded in 2011 with 469 deaths as shown below;

Death due to Boko Haram attacks

\begin{tabular}{|c|c|}
\hline Year & No killed \\
\hline 2009 & 4 \\
\hline 2010 & 330 \\
\hline 2011 & 469 \\
\hline 2012 & 369 \\
\hline 2013 & 169 \\
\hline & 1,341 \\
\hline
\end{tabular}

SOURCE: Compiled from Achumba and Ighomereho (2013),

Further, insecurity have resulted to a rise in incidences of kidnapping and assassinations. No wonder the number of assassinations continued to be on the increase. This was put at 1255 persons in year 2000, increasing by 1295 to 2550 in year 2004, until it got to an all-time high of 38,955 persons in year 2009. These assassinations also includes very high profile politically motivated killings, investigations for which are still ongoing and never ending. For instance, Alfred Rewane in 1994, Chief Bola Ige in 2001, Sunday Awoniyi in 2002, Marshal Harry in 2003, Ogbonnaya Uche in 2003, Aminosari Dikibo in 2004, Funsho Williams in 2006, Ayo Daramola in 2006, Dipo Dina in 2010, amongst others. 
Kidnapping and Assassination Statistics (2000 - 2013)

\begin{tabular}{|c|c|c|}
\hline Year & Kidnapping & Assassination \\
\hline 2000 & 243 & 2125 \\
\hline 2001 & 349 & 2117 \\
\hline 2002 & 337 & 2136 \\
\hline 2003 & 410 & 2550 \\
\hline 2004 & 349 & 2074 \\
\hline 2005 & 798 & 2000 \\
\hline 2006 & 372 & 1891 \\
\hline 2007 & 277 & 1956 \\
\hline 2008 & 309 & 38,955 \\
\hline 2009 & 703 & 2,114 \\
\hline 2010 & 738 & 1655 \\
\hline 2011 & NA & 2023 \\
\hline 2012 & 600 & 3143 \\
\hline 2013 & 574 & 65,989 \\
\hline TOTAL & 6,059 & \\
\hline
\end{tabular}

Source: Achumba and Ighomereho (2013),

NBS, Annual Abstract of Statistics, 2016

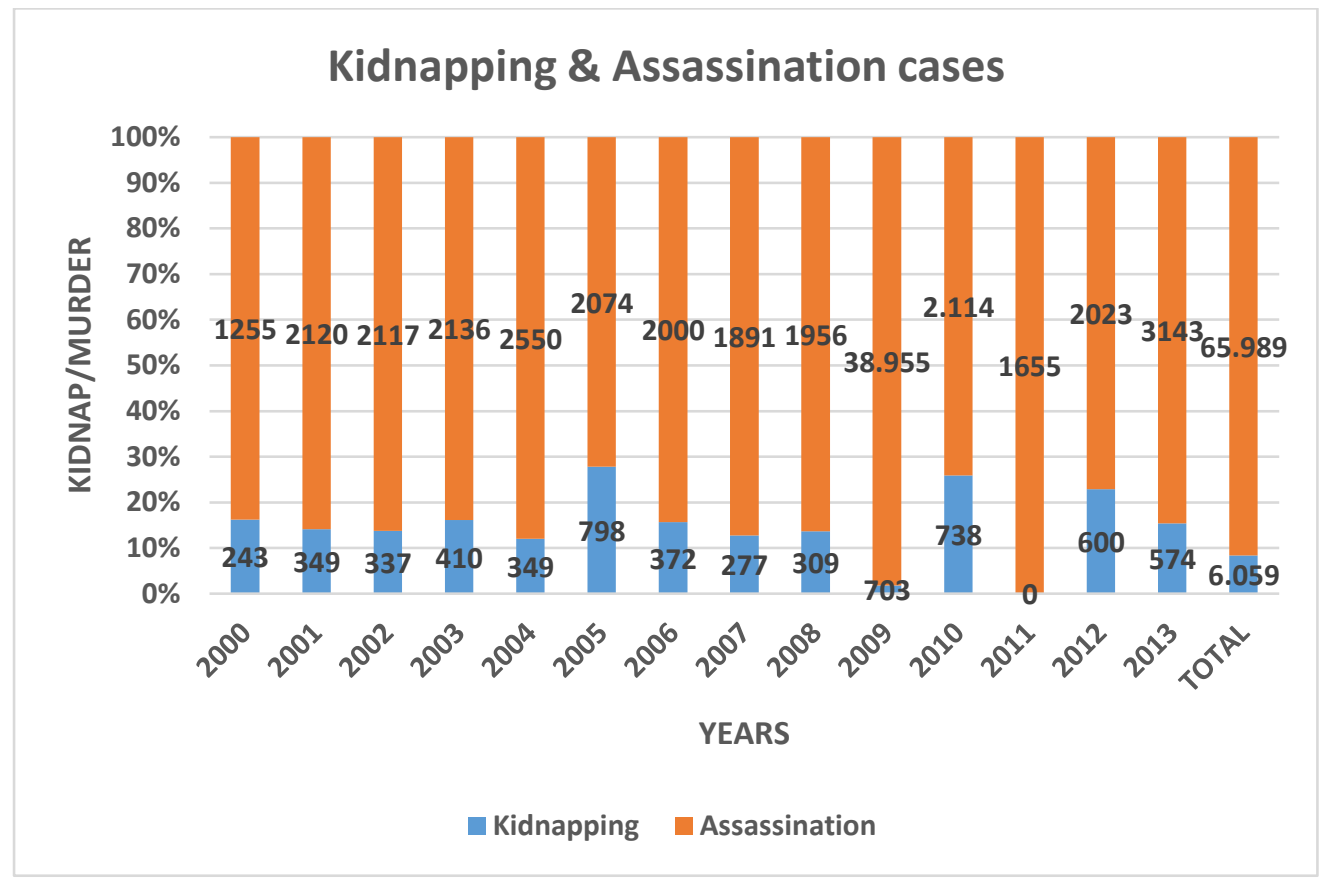

As evident from the graph, incidences of assassination continues to be on the rise reaching their peaks in 2009 with a total number of 38, 955 persons 
murdered. On the other hand, kidnapping continued to rise steadily peaking at 798 in 2005 and 738 in 2010.

\section{Effect on Oil Production, export and Oil revenue}

Exports were invariably negatively affected. This resulted from the general fall in production, a shift towards domestic markets, and disruptions in international markets. Foreign receipts from oil witnessed a steady drop from a high of $\$ 99,878$ in 2011 to an all-time low of $\$ 45,365$ in 2015 , representing a 55\% decrease over the figure in 2011. Consequently, oil production also declined steadily from 1974.80 barrel per day in 2011 to 1748.2 in 2015.

Oil Exports \& Production data

\begin{tabular}{|c|c|c|}
\hline Year & Oil Exports (Millions \$) & Production $(1,000 \mathrm{~b} / \mathrm{d})$ \\
\hline 2011 & 99,878 & $1,974.80$ \\
\hline 2012 & 96,905 & $1,954.10$ \\
\hline 2013 & 97,818 & $1,753.70$ \\
\hline 2014 & 82,586 & $1,807.00$ \\
\hline 2015 & 45,365 & $1,748.20$ \\
\hline
\end{tabular}

Source: OPEC Bulletin, 2016

In respect of revenue, Government revenue as a share of GDP mostly fell during periods of insecurity. Government expenditure invariably rose more than revenue, and budget deficits widened, financed by a combination of foreign and domestic borrowing, and increased money supply.

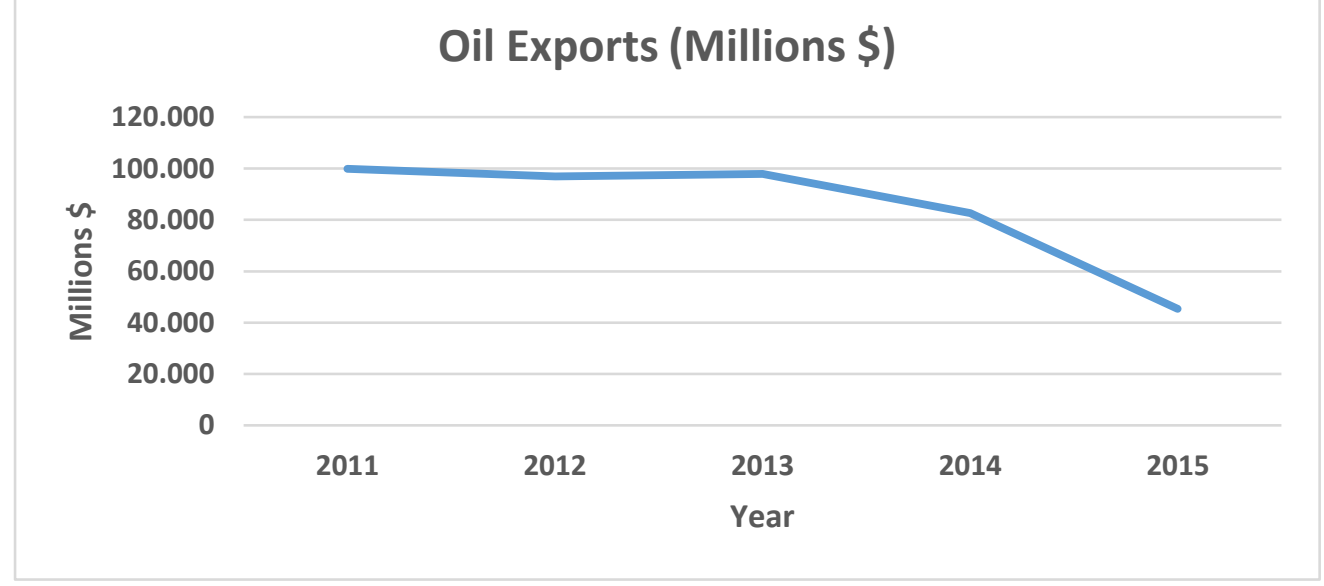

One reason for this persistent decline in export receipts and oil production is the militancy activities and the violent agitations for resource control in the Niger Delta resulting in massive destruction of oil installations, incessant pipeline vandalisation, oil theft and bunkering. As shown below, 
pipeline vandalisation occurred 3,505 times in 2013 when compared to 836 in 2010;

Pipeline Vandalisation, 2010 - 2013

\begin{tabular}{|c|c|c|c|}
\hline Year & Total occurrences & Product loss & Value loss Nmillon \\
\hline 2010 & 836 & 194.43 & 15,967 \\
\hline 2011 & 2,768 & 157.82 & 12,526 \\
\hline 2012 & 2,230 & 181.67 & 21,484 \\
\hline 2013 & 3.505 & 327.47 & $38,881.27$ \\
\hline
\end{tabular}

Source: NBS, Annual Abstract of Statistics, Vol. 2; 2016

\section{Effect on Unemployment}

Insecurity definitely results in the shutdown of businesses and the relocation of companies from unsafe to safe havens. Whereas the labour force continued to increase drastically but to 77.0 million in 2015 , from 73.0 million in 2014, representing an increase of 5.5 per cent, employment generation has not kept pace with that increase. Hence, the period witnessed continued increase in the number of unemployed. As shown, the number of unemployed in the labour force increased to 10.4 percent, compared to 7.8 per cent in 2014 , representing an increase of 2.6 percentage points.

\section{Labour force \& Unemployment Statistics}

\begin{tabular}{|c|c|c|}
\hline Year & Labour force (Millions) & Unemployment (\%) \\
\hline 2011 & $67,256,090$ & 6.0 \\
\hline 2012 & $69,105,775$ & 10.6 \\
\hline 2013 & $71,105,800$ & 10.0 \\
\hline 2014 & $72,931,608$ & 7.8 \\
\hline 2015 & $76,957,923$ & 10.4 \\
\hline
\end{tabular}

Source: CBN Annual Report, 2015.

\section{Unemployment (\%)}

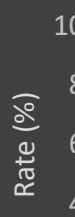

\section{0}

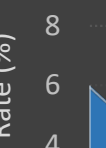

2

0 


\section{Effect on Agriculture}

The agricultural sector was never spared during uprising but particularly badly hit, especially as people were forced to move in the course of the conflicts. For instance, due to herdsmen's clashes in part of Benue, Kogi and Enugu State that resulted in destruction of farmlands, farm produce in those areas were low causing an increase in the prices of food items during the period. Further, agricultural activities has been brought to a complete halt in Borno State since the beginning of Boko Haram disturbances in that area. This is so because the people in some areas of the State have since relocated from their homes and farm land to internally displaced person's (IDP) camps for safety.

\section{Effect on the Informal Sector}

Insecurity causes sectoral shifts with a switch to subsistence and informal activities, including simple manufacturing production especially in North East and Niger Delta of Nigeria. Here, a number of companies operating in the area were forced to either scale down their operations or closed shop altogether due to the activities of Boko Haram and Militants. This resulted in unemployment and those disengaged found solace in the informal sector. Available data from the National Bureau of Statistics (NBS) showed that new jobs created in 2015 stood at 1,039,128, representing a 22.3 per cent increase, compared with 849,567 jobs created in 2014. The increase in job-creation was driven mainly by informal sector jobs, which accounted for 90.2 per cent of total, with the formal and public sectors accounting for only 8.8 and 1.0 per cent, respectively.

\section{Effect on Foreign Investment}

Foreign Direct Investment (FDI) are investments targeted at building new factories or investing in actual production activities which creates jobs. Achumba and Ighomereho (2013) noted that Insecurity discourages investment as it makes investment unattractive to business people. This is because it increases the cost of doing business either through direct loss of goods and properties or the cost of taking precautions against business risks and uncertainty. These costs could have a negative impact on business development and progress. 
Foreign and Portfolio Investment in Nigeria (2011-2015)

\begin{tabular}{|c|c|c|c|c|c|}
\hline Nature (\$B) & 2011 & 2012 & 2013 & 2014 & 2015 \\
\hline & $254,439.3$ & & & & \\
FDI - Other capital & 0 & $67,858.63$ & $30,065.76$ & $13,028.87$ & $4,210.41$ \\
\hline & $1,498,906$ & $1,979,333$. & $1,646,108$. & $2,292,466$. & $1,469,093$ \\
FDI - Equity & .99 & 15 & 03 & 24 & .22 \\
\hline Portfolio Investment - & $3,691,505$ & $11,655,83$ & $16,865,72$ & $11,448,16$ & $4,691,540$ \\
Equity & .55 & 5.94 & 4.28 & 0.95 & .41 \\
\hline & $5,444,851$ & $13,703,02$ & $18,541,89$ & $13,753,65$ & $6,164,844$ \\
& .84 & 7.72 & 8.07 & 6.06 & .04 \\
\hline
\end{tabular}

Source: CBN Annual Report, 2015.

Evidently, there has been a decline in foreign direct investment to Nigeria. FDI (other capital) continued to fall from a high of 254,439.3 billion dollars to 4,210.41 billion dollars representing over 100\% fall in FDI other capital during the period. Further, FDI equity fell by 56\% in 2015 compared to its position in 2014 in addition to portfolio investments that fell by $144 \%$ in 2015.This can be attributed to the state of insecurity in the country (social, economic and political instability) besides the issue of lack of regular electricity supply, which itself is a source of economic insecurity in the country.

\section{Foreign Direct Investment}

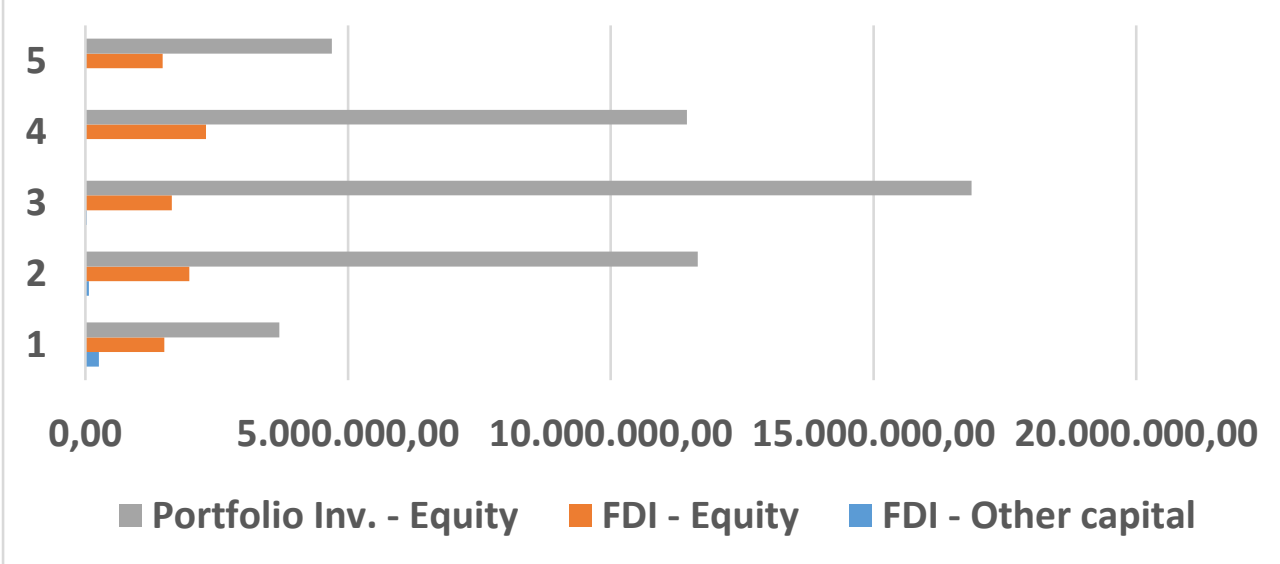

\section{Dealing With Insecurity In Nigeria}

The severity and hardships insecurity have caused the nation calls for a concerted and well-articulated security policies to address the hydra-headed problem. Analyst have suggested the need to understand the causes of insecurity so as to target the right solution to addressing the problem. Such solutions must be such that should be long lasting and all-encompassing to avoid a recurrence. 
According to Stan Flavius (2004), Contemporary intra-state conflicts cannot be prevented, resolved, or managed exclusively through preventive diplomacy, political negotiations, peacemaking, peacekeeping, and the use of force. They have complex causes (social inequality, state failure, human rights violations, resource predation, etc.) which require correlated international assistance in areas including sustainable economic growth, good governance, human rights protection, and environmental preservation.

This has become very important because of the case of the Niger-Delta militants that were granted amnesty but returned to vandalize oil pipelines and distort the Nation's inability to meet its oil production quota. Clearly, insecurity affects economic growth. Policies to target insecurity must address its root cause. The following are recommended;

i. $\quad$ Need for government to use revenue from primary commodity exports to fund effective basic delivery

ii. Need for government to diversify the economy away from dependence upon primary commodities

iii. Increase in government expenditure on internal security both in the recurrent and especially on the capital component.

iv. Acceleration of the pace of development and good governance.

v. A concerted and collaborative efforts by all security agencies of government to combat the menace of insecurity.

\section{Conclusion}

On the whole, a Nation replete with insecurity can never attract investments nor grow its economy. This study examined the effect of insecurity on economic growth and considered the likely effect of such insecurity on economic variables such as investment, employment, exports, government revenue and the informal sector.

Trends have shown evidently that insecurity is capable of drying-out investment, increasing unemployment, reducing export receipts and government revenue and by implication slows economic growth. Policies and Strategies to combat insecurity in Nigeria must target the population by eliminating or reducing to its barest minimum the massive loss of life in areas of violent activities, target oil production, exports and oil revenue by eliminating pipeline vandalisation activities, oil bunkering and militancy struggles in the Niger-Delta of Nigeria, target unemployment by creating enabling and peaceful environment for businesses to operate and for investments to strive.

Such policies and strategies must equally target the agricultural sector by reducing communal conflicts, herdsmen clashes and the destruction of farmlands and produce following from these clashes. Further, it should target foreign investments by creating an enabling environment for investment to 
strive, ensure peaceful and safe haven for MNCs to operate and do business and provide the requisite infrastructure that will attract new investments. Especially, it should target government expenditure by increasing budgetary allocations to both the recurrent and capital component of internal security.

In sum, whereas trend analysis was used to establish the relationship between insecurity and economic growth in this study, it is believed that a rigorous and more advanced empirical technique can be used to properly dimension the likelihood of effect between the dependent variable (insecurity) and the various explanatory variables in this study (including but not limited to investment, oil prices, exports, unemployment, inflation, government revenue, informal sector etc.). This should be the direction of future research.

\section{References:}

1. Achumba Ighomereho and Akpor-Robaro (2013). 'Security Challenges in Nigeria and the Implications for Business Activities and Sustainable Development', Journal of Economics and Sustainable Development, ISSN 2222-1700 (Paper) ISSN 2222-2855 (Online). Vol.4, No.2, 201379.

2. Aderoju, Oyefusi (2007). 'Oil-dependence and civil conflict in Nigeria', PhD. Dissertation submitted to the Economics Department, University of Benin, Nigeria. June.

3. Beland, D. (2005). 'The Political Construction of Collective Insecurity: From Moral Panic to Blame Avoidance and Organized Responsibility'. Centre for European Studies, Working Paper.

4. Central Bank of Nigeria (2012 \& 2015). Annual Reports and Statement of Accounts, Garki, Abuja. December

5. Collier, Paul and Anke Hoeffler. 2000."Greed and Grievance in Civil War." 42. Washington, D.C.: World Bank, 30, 11, 1845-64.

6. Collier Paul (2006). 'Economic Causes of Civil Conflict and their Implications for Policy'. Oxford University, April.

7. Descriptive Statistics. Web Center for Social Research methods`. Available online at https://www.socialresearchmethods.net/kb/statdesc.php.

8. Ewetan, Olabanji and Urhie, Ese (2014). 'Insecurity and SocioEconomic Development in Nigeria'. Journal of Sustainable Development Studies ISSN 2201-4268 Volume 5, Number 1.

9. Global Peace Index (GPI, 2012). Global Peace Ranking. Institute for Economic and Peace, Retrieved from Wikipedia, the free encyclopedia.

10. European Union, (2004). 'Securing Peace and Stability for Africa'. The EU Funded African Peace Facility, Brussels 
11. National Bureau of Statistics (2016). Annual Bureau of Statistics, Vol. 1 \& 2, Central Business District, Abuja. July 2017.

12. Nnamdi Asika (2004). Research Methodology in the Behavioural Sciences, Lagos, 2004. Page 114\&118.

13. Omoyibo, K. U., \& Akpomera, E. (2013). 'Insecurity Mantra: The Paradox of Nigerian Growth and Development'. European Scientific Journal, 8(15), 132-142.

14. SIPRI yearbook (2015). 'Armaments, Disarmament and International Security', Oxford University Press, Stockholm International Peace Research Institute.

15. Stan, Flavius (2004). 'The Security-Development Nexus: Conflict, Peace and Development in the $21^{\text {st }}$ Century'. Internal Peace Academy, West Point, New York, 3-7 May.

16. Stewart, Frances (2004). 'Development and Security', WORKING PAPER 3, Centre for Research on Inequality, Human Security and Ethnicity, CRISE Queen Elizabeth House, University of Oxford

17. Stewart, Frances, Valpy Fitzgerald et al. (2001). 'War and Underdevelopment: The Economic and Social Consequences of Conflict'. Vol. 1. Oxford: Oxford University Press.

18. Tilahun Nigatu (2009). Qualitative Data Analysis, M\&E and Research, African Medical and Research Foundation, March 2009.

19. UN Secretary-General (2004). 'Implementation of the recommendations contained in the report of the Secretary-General on the causes of conflict and promotion of durable peace and sustainable development in Africa', Progress report of the Secretary-General (UNDoc.: A/59/285), New York 